C. Human Rights and National Legal Orders 


\title{
Judicial and Prosecutorial Independence in Europe: How Politicized Judges and Prosecutors Undermine the Right to a Fair Trial in Eastern Europe and Central Asia
}

\author{
Stefanie Lemke
}

\section{A. Introduction}

This chapter looks at how Europe's fast-growing number of politicised judges and prosecutors impact the application of the European Convention on Human Rights (ECHR) and the execution of judgments of the European Court of Human Rights (ECtHR) in Council of Europe (Coe) member countries, particularly with regard to Article 6 of ECHR (right to a fair trial). In 2013, the UN Special Rapporteur on the Situation of Human Rights Defenders warned that governments increasingly abuse the judicial system to criminalize and stigmatize activists for their human rights work. ${ }^{1}$ In regard to Europe, there are more and more governments that are vested with far-reaching competences and use their powers to undermine the judicial process. This is especially visible in political sensitive cases where domestic courts disregard the ECHR and the jurisprudence of the ECtHR. Courts side with the prosecution and grant arbitrary arrests and detentions, leave lawyers little time to prepare their clients' defence, deny access to court files and refuse to hear witnesses in the defence's favour. ${ }^{2}$ Azerbaijan, for instance, has a long history of violating the procedural rights of human rights defenders in spite of having been repeatedly reminded by the ECtHR to comply with the ECHR and the

1 UN Human Rights Council, Report of the Special Rapporteur on the situation of human rights defenders, Margaret Sekaggya, 23 December 2013, UN Doc. A/HRC/25/55, para. 59 .

2 Human Rights Watch, 'Crimea: Defence Lawyers Harassed, Drop Bogus Charges Against Crimean Tatars’, 2017, https:/www.hrw.org/news/2017/01/30/crimea-defe nse-lawyers-harassed; OSCE, Trial Monitoring Report, Azerbaijan, 2011, www.osc e.org/baku/100593; CoE Parliamentary Assembly, The Progress of the Assembly's Monitoring Procedure (January-December 2019), Resolution 2325 (2020), 30 January 2020; CoE Parliamentary Assembly, The Functioning of Democratic Institutions in Azerbaijan, Resolution 2062 (2015), 23 June 2015. 
Court's case law. ${ }^{3}$ Yet Azerbaijani courts found the activist Rasul Jafarov guilty of forgery and other offences after he had criticised the Azerbaijani government at a CoE event, without basing their actions on sufficient evidence, ${ }^{4}$ and opted for disbarring the lawyer Khalid Bagirov following his remarks in a trial where Mr. Bagirov had represented an opposition politician and questioned the impartiality of Azerbaijan's judiciary. ${ }^{5}$ Against this background, this chapter looks at the interplay between politics and courts in three CoE member countries - Azerbaijan, Russia and Ukraine - which are known for their oppression of critical voices. It provides an in-depth analysis of how governments control judicial systems and, as a result of this, judges and prosecutors ignore European human rights standards in cases involving activists and other regime critics.

\section{B. The Role and Responsibilities of Judges and Prosecutors}

Judges and prosecutors are supposed to set an example to society in the protection of human rights, meaning that their actions should respond to human rights standards. Governments, however, can exert significant influence over the judicial process if they abandon the rule of law including the separation of powers. In that case, judges and prosecutors may be less likely to hold the government responsible for its wrongdoings and deliver justice. ${ }^{6}$ The international community has therefore developed a variety of regulations to remind judges and prosecutors of their powerful role in the judicial process and the importance to uphold human rights standards, including the right to a fair trial, in their day-to-day work. ${ }^{7}$

3 See, for example, ECtHR, Judgment, 26 October 2011, Huseyn and others $v$ Azerbaijan, Application Nos. 35485/05, 45553/05, 35680/05 and 36085/05 and ECtHR, Judgment, 14 June 2013, Insanov v Azerbaijan, Application No. 16133/08.

4 ECtHR, Judgment, 17 March 2016, Rasul Jafarov v Azerbaijan, Application No. 69981/14, para. 178.

5 ECtHR, Judgment, 25 September 2020, Bagirov v Azerbaijan, Application No. $81024 / 12$ and 28198/15.

6 See, for example, ECtHR, Judgment, 8 August 2006, H.M. $v$ Turkey, Application No. 34494/97; ECtHR, Judgment, 22 May 2014, Ilgar Mammadov v Azerbaijan, Application No. 15172/13; ECtHR, Judgment, 2 February 2017, Navalnyy v Russia, Application No. 29580/12 and 4 more.

$7 \mathrm{UN}$, Seventh UN Congress on the Prevention of Crime and Treatment of Offenders, Milan, 26 August-6 September 1985, Basic Principles on the Independence of the Judiciary (1986), 58, para. 6; Consultative Council of European Judges (CCJE), Magna Carta 
Ideally, judges should be appointed and promoted on a basis of merit by an independent, impartial and purely judicial body (in the form of a judicial council) which is supposed to make judges less vulnerable to internal and external pressures as they possess the necessary skills to perform their role. ${ }^{8}$ Other than that lengthy probationary periods, case-assignments, forced retirement due to age, lack of protection from salary adjustments and judicial removal procedures that are made on the basis of personal and political considerations can impact significantly a judge's impartial decision-making. ${ }^{9}$ Generally, judges should be neutral servants of 'the law' who apply the law with integrity and free of corruption. ${ }^{10}$ They should be the 'watchdogs of the political process' who guarantee fair proceedings. ${ }^{11}$ The Magna Carta of Judges, for example, requires judges to

of Judges (Fundamental Principles), 17 November 2010, https://rm.coe.int/2010 -ccje-magna-carta-anglais/168063e431, paras. 1, 16; International Association of Judges, The Universal Carter of the Judge, 14 November 2017, https://www.un odc.org/res/ji/import/international_standards/the_universal_charter_of_the_ judge/universal_charter_2017_english.pdf, Article 1; International Association of Prosecutors, Standards of Professional Responsibility and Statement of the Essential Duties and Rights of Prosecutors, 23 April 1999, https:/www.iap-associa tion.org/getattachment/Resources-Documentation/IAP-Standards-(1)/English.pdf .aspx, 3(e), (f); UN, Eighth UN Congress on the Prevention of Crime and Treatment of Offenders, Havana, 27 August-7 September 1990, Guidelines on the Role of Prosecutors (1990), 189 para. 14.

$8 \mathrm{CoE}$, Challenges for Judicial Independence and impartiality in the Member States of the Council of Europe, SG/Inf(2016)3rev, 24 March 2016, 4; Domingo, 'Judicial Independence and Judicial Reform in Latin America' in Schedler et al. (eds), The Self-Restraining State: Power and Accountability in New Democracies (1999), 151 (154); Fiss, 'The Right Degree of Independence' in Strotzky (ed), Transition to Democracy in Latin America: The Role of the Judiciary (1993), 55 (59); Jackson, 'Judicial Independence: Structure, Context, Attitude', in Seibert-Fohr (ed), Judicial Independence in Transition (2012), 19, 26, 28.

$9 \mathrm{CoE}$, Challenges for Judicial Independence and impartiality in the Member States of the Council of Europe, SG/Inf(2016)3rev, 24 March 2016, 6; Fiss, 'The Right Degree of Independence' in Strotzky (ed), Transition to Democracy in Latin America: The Role of the Judiciary (1993), 55 (58 f.); Jackson, 'Judicial Independence: Structure, Context, Attitude', in Seibert-Fohr (ed), Judicial Independence in Transition (2012), 19 (36, 49, 53); Transparency International, Global Corruption Report 2007 (2007), 7.

10 Shapiro and Stone Sweet, 'Law, Courts and Social Science' in Shapiro and Stone Sweet (eds), On Law, Politics and Judicialization (2002), 1 (3).

11 UN, Seventh UN Congress on the Prevention of Crime and Treatment of Offenders, Milan, 26 August-6 September 1985, Basic Principles on the Independence of the Judiciary (1986), 58, para. 6; Consultative Council of European Judges (CCJE), 'Magna Carta of Judges (Fundamental Principles)', 17 November 2010, https://rm.coe.int/ 2010-ccje-magna-carta-anglais/168063e431, paras. 1, 16; International Association 
perform their duties without bias, respect the presumption of innocence and safeguard the equality of arms between the defence and the prosecution in criminal cases; furthermore, judges should base their decisions on the application of legal rules, through legal reasoning and findings of facts that are based on evidence and analysis, and avoid the use of contempt proceedings to restrict legitimate public criticism of the courts. ${ }^{12}$ Judges should also ensure that suspects are represented by a lawyer. Such legal assistance should be effective and practical, meaning that lawyers should not be allowed to only be present but also to actively assist their clients: they should be given adequate time and facilities to prepare the client's defence, be able to communicate with their client in private, put forward her/his version of events and present the case under conditions that do not place their client at a disadvantage vis-à-vis their opponent. ${ }^{13}$

Prosecutors also have a vital role in the administration of justice by, inter alia, instituting prosecutions and supervising the legality of investigations. ${ }^{14}$ The prosecution can be part of the judiciary (in civil law systems)

of Judges, The Universal Carter of the Judge, 14 November 2017, https:/www.un odc.org/res/ji/import/international_standards/the_universal_charter_of_the_judg e/universal_charter_2017_english.pdf, Article 1.

12 UN Economic and Social Council, Strengthening basic principles of judicial conduct, Annex, Bangalore Principles ofJudicial Conduct, 27 July 2006, UN Doc. E/Res/2006/23, Values 5, 11; CCJE, 'Magna Carta of Judges (Fundamental Principles)', 17 November 2010, https://rm.coe.int/2010-ccje-magna-carta-anglais/168063e431, paras. 5, 11; Judicial Integrity Group, Measures for the Effective Implementation of the Bangalore Principles of Judicial Conduct, 21/22 January 2010, https:/www.un odc.org/res/ji/import/international_standards/measures_implementation/measure s_implementation.pdf, para. 9.5.

13 ECtHR, Judgment, 18 March 1997, Foucher v France, Application No. 22209/93, para. 34; ECtHR, Judgment (GC), 12 May 2005, Öcalan v Turkey, Application No. 46221/99, para. 140; ECtHR, Judgment, 15 November 2007, Galstyan v Armenia, Application No. 26986/03, para. 84; ECtHR, Judgment, 12 January 2012, Iglin v Ukraine, Application No. 39908/05, para. 65; ECtHR, Judgment (GC), 27 November 2008, Salduz v Turkey, Application No. 36391/02, paras. 53 f.; ECtHR, Judgment, 10 July 2012, Gregačević v Croatia, Application No. 58331/09, para. 51; ECtHR, Judgment (GC), 13 September 2016, Ibrahim and Others $v$ United Kingdom, Application No. 50541/08 and 3 more, para. 255; ECtHR, Judgment, 26 January 2017, Faig Mammadov v Azerbaijan, Application No. 60802/09, para. 19.; ECtHR, Judgment, 12 May 2017, Simeonovi v Bulgaria, Application No. 21980/04, para. 112.

14 UN, Eighth UN Congress on the Prevention of Crime and Treatment of Offenders, Havana, 27 August-7 September 1990, Guidelines on the Role of Prosecutors (1990), 189 paras. 3, 11; UN Office on Drugs and Crime (UNODC), The Status and Role of Prosecutors. A UN Office on Drugs and Crime and International Association 
or part of the executive (in common law systems). ${ }^{15}$ Either way, prosecutors, like judges, owe the public a deep and abiding commitment to the rule of law, including to respect the right to a fair trial. ${ }^{16}$ The UN Guidelines on the Role of Prosecutors, for example, note that prosecutors are to 'respect and protect human dignity and uphold human rights'. ${ }^{17}$ Functional independence from their hierarchy and being autonomous in their decision making are crucial for prosecutors to guarantee due process and the smooth functioning of the criminal justice system. ${ }^{18}$ Being a prosecutor therefore comes with several duties and responsibilities, such as ensuring that the police regard legal principles, a suspect is brought promptly before a judge and refusing to use evidence that was illegally obtained. ${ }^{19}$

In practice, however, there is a considerable divergence in how these rules are applied. In the following, this shall be illustrated by a study of judicial systems in Azerbaijan, Russia and Ukraine, where judicial authorities disregard European human rights standards in cases involving political sensitive matters.

of Prosecutors Guide, 2014, https://www.unodc.org/documents/justice-and-pr ison-reform/HB_role_and_status_prosecutors_14-05222_Ebook.pdf, 38. UN Guidelines on the role of prosecutors (1990) rule 3, 11.

15 Myjer et al. (eds), Human Rights Manual for Prosecutors (2008); UNODC, The Status and Role of Prosecutors. A UN Office on Drugs and Crime and International Association of Prosecutors Guide, 2014, https://www.unodc.org/documents/justic e-and-prison-reform/HB_role_and_status_prosecutors_14-05222_Ebook.pdf, $16 \mathrm{ff}$.

16 International Association of Prosecutors, 'Standards of Professional Responsibility and Statement of the Essential Duties and Rights of Prosecutors', 23 April 1999, https:/www.iap-association.org/getattachment/Resources-Documentation/I AP-Standards-(1)/English.pdf.aspx, 3(e), (f).

17 UN, Eighth UN Congress on the Prevention of Crime and Treatment of Offenders, Havana, 27 August-7 September 1990, Guidelines on the Role of Prosecutors (1990), 189, para. 14.

18 Ibid.

19 Consultative Council of European Prosecutors, Opinion No.9 (2014). European norms and principles concerning prosecutors, 17 December 2014, https://rm.coe.i nt/168074738b, para. 24; Convention against Torture and Other Cruel, Inhuman or Degrading Treatment or Punishment; UN, Eighth UN Congress on the Prevention of Crime and Treatment of Offenders, Havana, 27 August-7 September 1990, Guidelines on the Role of Prosecutors (1990), 189 paras. 12, 14, 16; UNODC, 'The Status and Role of Prosecutors. A UN Office on Drugs and Crime and International Association of Prosecutors Guide', 2014, https://www.unodc.org/documents/justi ce-and-prison-reform/HB_role_and_status_prosecutors_14-05222_Ebook.pdf, 38. 


\section{Country Studies}

\section{Azerbaijan}

In theory, suspects enjoy a range of basic procedural rights pursuant to Article 91 of Azerbaijan's Criminal Procedure Code. This includes: the right to sufficient time to prepare their defence, to request law enforcement bodies to give access to court files and make copies of them, to make a statement on the accuracy and completeness of written records, and to request the inclusion of relevant 'circumstances' to such records. In practice, however, Azerbaijan's judiciary is heavily used as a tool to penalize human rights defenders. ${ }^{20}$ The separation of powers is non-existent, with the judiciary being controlled by the Aliyev family since 1993. After Ilham Aliyev had succeeded his father as president in 2003, he was re-elected for his fourth term in office in 2018 amid evidence of electoral fraud. ${ }^{21}$ The Azerbaijani constitution gives the president broad authority over the judicial system and parliament, leading to a judiciary that is totally subservient to the executive branch. The constitution allows the president to nominate the candidates for judicial office in the higher courts, including the constitutional court and the supreme court. ${ }^{22}$ Although consent of the legislator is needed for their appointment, it is likely that the nominees will be approved by parliament as it mainly consists of pro-government parties. The latest (snap) elections were held in 2020, with the OSCE questioning 'whether the [election] results were established honestly'. ${ }^{23}$ Additionally, the president is authorised to appoint all chief justices and the prosecutor general, without the approval of parliament. ${ }^{24}$ The president can also veto appointments of the prosecutor general and oversees the selection process

20 See, for example, Amnesty International, Amnesty International Report 2017/18. The State of the World's Human Rights (2018), 83.

21 OSCE: 'Azerbaijan Election Lacked Genuine Competition in an Environment of Curtailed Rights and Freedoms, International Observers Say', 12 April 2018, http://www.osce.org/odihr/elections/azerbaijan/377623.

22 Article 130(2) of the The Constitution of the Republic of Azerbaijan, 2020, https:/ /en.president.az/azerbaijan/constitution.

23 Freedom House, Freedom in the World 2020 (2021); OSCE: 'Despite Large Number of Candidates, Azerbaijan Elections Lacked Genuine Competition and Choice, International Observers Say', 10 February 2020, https://www.osce.org/odihr/electi ons/azerbaijan/445762.

24 Azerbaijani Constitution Article 133(4). 
of lower court judges. ${ }^{25}$ The latter are nominated by the Legal Judicial Council but their appointment must be approved by the president. ${ }^{26}$ The Legal Judicial Council is a self-governing body with strong links to the government, over which the minister of justice has presided since its creation in 2005. Besides, nine out of the judicial council's 15 members are judges appointed by the president, two of its members are selected jointly by the president and parliament, and two members are chosen by the prosecutor's general office and the board of the national bar association, respectively. ${ }^{27}$ The judiciary is further controlled by a lengthy, three-year probationary period for judicial candidates, encouraging them to align their viewpoints with their hierarchy to secure reappointment. ${ }^{28}$

Azerbaijani judges and prosecutors constantly violate the concept of equality of arms. The Committee against Torture found that Azerbaijan's government abuses its authority and uses judicial authorities to violate rule of law obligations. ${ }^{29}$ It is common practice that human rights defenders are arbitrarily deprived of their liberty and subjected to ill-treatment to silence them for their professional activities. ${ }^{30}$ Among those human rights defenders who have suffered ill-treatment are Emin Husyenov Intigam, Ali Aliyev, Rasul Jafarov, Rashad Hassanov, Panah Chodar oglu Huseyn, and Leyla Yunusova. Courts impose travel bans on human rights activists to stop them from leaving Azerbaijan. The journalist Emin Husyenov, for example, was prevented from travelling to Istanbul by border guards at Baku International Airport. ${ }^{31}$ In another case, in Aliyev v. Azerbaijan, the

25 Article 93(1) of the 1997 Courts and Judges Act of the Republic of Azerbaijan, 2006, https://www.legislationline.org/download/id/3843/file/Azerbaijan_Courts Judges_Act_1997_am_2006_en.pdf; Article 1, 4(1) of the Judicial-Legal Council Act of the Republic of Azerbaijan, 2014, https://www.legislationline.org/downloa d/id/8619/file/Azerbaijan_law_judicial_legal\%20council_2004_am2014_en.pdf.

26 Ibid.

27 CoE Directorate General Human Rights and Rule of Law, Eastern Partnership. Enhancing Judicial Reform in the Eastern Partnership Countries. Efficient Judicial Systems Report 2014, 2014, https://rm.coe.int/eastern-partnership-enhancing-judici al-reform-in-the-eastern-partnersh/1680788f3e.

28 Amendment to the Azerbaijani Courts and Judges Act, adopted on 11 February 2015. See also, for example, ECtHR, Judgment, 30 November 2010, Henryk Urban and Ryszard Urban v Poland, Application No. 23614/08, para. 53.

29 UN Committee against Torture (UN CAT), Concluding observations on the fourth periodic report of Azerbaijan, 27 January 2016, UN Doc. CAT/C/AZE/CO/4, 3.

30 Ibid.

31 CoE Commissioner for Human Rights, Concerns over the situation of human rights defenders in Azerbaijan, 7 August 2014, https://www.coe.int/en/web/commissioner /-/concerns-over-the-situation-of-human-rights-defenders-in-azerbaijan. 
lawyer Ali Aliyev, a vocal government critic and head of the NGO 'Legal Education Society', was detained and convicted by the authorities for his human rights work. ${ }^{32}$ In 2014, his NGO, which had compiled a list of political prisoners in Azerbaijan, helped victims of politically motivated convictions and represented them at the ECtHR, was raided and subsequently closed amid a crackdown on dissident voices in Azerbaijan. ${ }^{33} \mathrm{Mr}$. Aliyev was then summoned to the prosecutor general's office as a witness in a criminal case against various local NGOs and questioned about his background, his family and his human rights activities. ${ }^{34}$ Following his interview with the prosecutor's general office, Mr. Aliyev was detained on the suspicion of embezzlement, forgery and tax evasion, which the local district court justified by the seriousness of the charges against Mr. Aliyev and prevented him from leaving Azerbaijan. ${ }^{35} \mathrm{He}$ appealed against this decision and the search of his NGO's office unsuccessfully. In this context, the ECtHR observed various similarities of Mr. Aliyev's case to the case of Rasul Jafarov, another human rights defender against whom charges of embezzlement, forgery and tax evasion were pressed by Azerbaijani courts. ${ }^{36}$ In the case of Mr. Jafarov, the ECtHR condemned Azerbaijani courts for limiting their role to the automatic endorsement of the prosecution's applications. The ECtHR found that the local courts failed to verify the existence of any suspicion against Mr. Jafarov: there was no evidence showing that Mr. Jafarov had engaged in the criminal activities of which he was accused. ${ }^{37}$ Likewise, the ECtHR criticised the prosecution's decision to bring charges against Rashad Hasanov and other members of the NGO NIDA without any evidence to support its accusations..$^{38} \mathrm{Mr}$. Hasanov and his colleagues were unlawfully accused of having obtained Molotov cocktails and storing them in their flats after they had organised and participated in peaceful anti-government protests in Baku, which led to their detention. Despite the lack of a reasonable suspicion against them, judges ordered and extended their pre-trial detention, having agreed to the

32 ECtHR, Judgment, 20 September 2018, Aliyev v Azerbaijan, Application Nos. $68762 / 14$ and $71200 / 14$, paras. $213 \mathrm{ff}$.

33 Id. para. 23.

34 Id. para. 10.

35 Id. paras. 22, 24.

36 Id. paras 207, 214.

37 ECtHR, Judgment, 17 March 2016, Rasul Jafarov v Azerbaijan, Application No. 69981/14, paras. $128 \mathrm{ff} ., 143 \mathrm{f}$.

38 ECtHR, Judgment, 7 June 2018, Rashad Hasanov and Others $v$ Azerbaijan, Application No. $48653 / 13$ and 3 more, para. 105 . 
prosecution's requests to remand them in custody. ${ }^{39}$ In Huseyn and Others v. Azerbaijan, Mr. Huseyn's lawyers were not given 'sufficient access to the prosecution's evidence after the pre-trial investigation had been completed and before the trial had commenced nor had they enjoyed such access after the trial had commenced, despite their repeated complaints to that effect'. ${ }^{40}$ The ECtHR noted that restricting access to court documents gives rise to 'serious problems' as to the adequacy of the time and facilities afforded to the defence within the Azerbaijani criminal justice system, emphasising that the defence must be given the opportunity to have knowledge of and comment on the observations filed and the evidence adduced by the prosecution..$^{41}$ In the case of the civil society activist Leyla Yunusova, disciplinary proceedings were instituted against her lawyer, $\mathrm{Mr}$. Bagirov, by the Azerbaijani Bar Association of which Mr. Bagirov was a member. ${ }^{42}$ Prior to this, Mr. Bagirov's requests for a copy of the administrative decision depriving his client of her right to make phone calls and denying a list of prescribed medication to Ms. Yunusova, who suffers from chronic hepatitis, had remained unanswered by the authorities. ${ }^{43}$ Being suspended from practicing, Mr. Bagirov was then banned from meeting with Ms. Yunusova who was held in detention at that time. ${ }^{44}$ Lastly, in Insanov v. Azerbaijan, the ECtHR found a violation of the rights of the defence, particularly the right to effective legal assistance. ${ }^{45}$ After being questioned by the police, the former health minister Ali Insanov was detained on suspicion of numerous acts of embezzlement of public property, abuse of official authority and complicity in an attempted coup d'état, allegedly being planned to take place after the parliamentary elections in 2005. Mr. Insanov's home was searched where the police found large amounts of cash in various currencies, large quantities of gold items and jewellery, and deeds of various residential properties. At pre-trial stage, $\mathrm{Mr}$. Insanov's lawyers had only restricted access to their client and his court

39 Id. paras. 105, 107.

40 ECtHR, Judgment, 26 July 2011, Huseyn and Others $v$ Azerbaijan, Application No. $35485 / 05$ and 3 more, para. 175.

41 Id. para 175.

42 ECtHR, Judgment, 16 July 2020, Yunosova and Yunosov v Azerbaijan (No. 2), Application No. 68817/14, para. 73.

43 ECtHR, Judgment, 2 June 2016, Yunosova and Yunosov v Azerbaijan, Application No. 59620/14, paras. $42 \mathrm{f}$.

44 ECtHR, Judgment, 16 July 2020, Yunosova and Yunosov v Azerbaijan (No. 2), Application No. 68817/14, para. 73.

45 ECtHR, Judgment, 14 March 2013, Insanov v Azerbaijan, Application No. 16133/08, paras. $165 \mathrm{ff}$. 
file. They were not allowed to familiarise themselves with Mr. Insanov's exceptionally voluminous case file prior to the commencement of the trial, which would have required examination and assessment of an immense amount of documentary evidence, witness statements and other material. ${ }^{46}$ Besides, his lawyers were not allowed to examine witnesses, see their client on weekends or confer with him in a confidential setting for a reasonably lengthy period of time during the court sessions, which took place without breaks and lasted full days. ${ }^{47}$ This forced Mr. Insanov's lawyers to discuss requests and submissions at the court hearings themselves where they spoke through the bars of the metal cage to their client - in the presence of the judge, the prosecution, the audience and other trial participants. ${ }^{48}$ Later, the ECtHR held that, in a democratic society, the right to consult with a lawyer is a basic requirement of a fair trial, which the Azerbaijani courts failed to guarantee in the case of Mr. Insanov. ${ }^{49}$

\section{Russia}

Russia's criminal justice system suffers from a selective approach to justice and severe levels of corruption, being ranked $101^{\text {st }}$ out of 128 countries and thus as one of the most corrupt countries worldwide. ${ }^{50}$ Judges and prosecutors, like their Azerbaijani counterparts, ignore constitutional guarantees such as the equality of arms, breaching systematically the procedural rights of anti-government voices. Institutions to safeguard the legal order are absent in Russia which is mainly due to the prosecution's broad authority. ${ }^{51}$ Russia's General Prosecutor, unlike his Western European counterparts, is vested with a general supervisory function that endows him with extremely far-reaching rights. The General Prosecutor is tasked with monitoring the implementation of legal acts including anti-extremism legislation and oversees the compliance of authorities and private enti-

46 Id. para. 166.

47 Id. paras. 161, 167.

48 Id. para. 168.

49 Id. para. 165.

50 Freedom House, Freedom in the World 2019 (2020); World Justice Project, The World Justice Project Rule of Law Index 2019 (2019).

51 European Commission for Democracy through Law (Venice Commission), Opinion on the Federal Law on the Prokuratura (Prosecutor's Office) of the Russian Federation, 13 June 2015, CDL-AD(2005)014, 12; Venice Commission, Compilation of Venice Commission Reports Concerning Prosecutors, 11 November 2017, CDL$\operatorname{PI}(2018) 001,11$. 
ties (e.g., local authorities, military officials, NGOs, etc.) with European and international human rights standards. $\mathrm{He}$ is also allowed to enter the premises of these authorities and organisations and access their documents and materials to perform his tasks, without the need to justify his actions on reasonable and objective grounds..$^{52}$ His requests are subject to 'unconditional execution', meaning that his actions have binding effect. ${ }^{53}$ Given that 'such broadly defined general supervisory function was a logical component of the [former Soviet] system of unity of power and resulted from that system's lack of administrative and constitutional courts and the institution of an ombudsman', the Venice Commission recommended Russia in its 2005 report to limit the prosecution's influence. ${ }^{54}$ It also pointed out that, in a democratic, law-governed state, the protection of the rule of law should be 'the task of independent courts'. ${ }^{55}$ In 2013, the General Prosecutor, however, launched a nationwide campaign of unannounced inspections of human rights groups, which resulted in about 1,000 NGOs being searched by lower rank prosecutors and officials of the ministry of justice, the federal tax authority and other government agencies. $^{56}$ Later, a report published by the 'Closed Society' showed that the inspections targeted particularly organisations that cover political sensitive topics and receive foreign funding, such as Russian NGOs and national chapters of foreign human rights groups including Amnesty International and Human Rights Watch. ${ }^{57}$

Well documented is also the gross misconduct of judges who side with prosecutors in trials against human rights defenders and other critics..$^{58}$ In general, the right to a fair trial is one of Russia's most frequently violated rights, with a striking number of cases originating from the North

52 Article 1(1) of the Federal Law No. 2202-I of January 17, 1992 on the Prosecutor's Office of the Russian Federation, 2007, https://www.wto.org/english/thewto_e/acc e/rus_e/WTACCRUS58_LEG_83.pdf.

53 Articles 6, 21, 22 of the Federal Law on the Prosecutor's Office.

54 Venice Commission, Opinion on the Federal Law on the Prokuratura (Prosecutor's Office) of the Russian Federation, 13 June 2015, CDL-AD(2005)014, 12.

55 Ibid.

56 Human Rights Watch, Laws of Attrition (2013); The Prosecutor General's Office of the Russian Federation, Report. Order of 27 December 2012, N 27-072012/14п1861-12в, 2012, http://genproc.gov.ru/smi/interview_and_appearences/a ppearences $/ 83568 /$.

57 Closed Society (2015).

58 Amnesty International, Unfair Game (2019). 
Caucasus. ${ }^{59}$ There is, for example, a high number of pre-trial detentions of activists, which were requested by the prosecution and were almost automatically granted by the courts. ${ }^{60}$ The UNHCR also observed a low acquittal rate and a high percentage of acquittals overturned on appeal in cases concerning political sensitive matters. ${ }^{61}$ For instance, the environmental activists Suren Gazaryan and Evgeny Vitishko of the NGO 'Environmental Watch on North Caucasus' were sentenced to three years in prison for protesting against a fence in the run-up of the Sochi Olympics. The fence had been illegally constructed in a forest and surrounded the residence of the then governor of the Krasnodar region and later federal minister of agriculture Aleksandr Tkachov on which they spray-painted 'This is our forest'. ${ }^{62}$ Ms Gazaryan and Mr. Vitishko were subsequently charged with damage to property and their defence ignored. Judges dismissed the argument by their lawyer that the fence had been constructed illegally as not relevant to the case and the prosecution denied even the very existence of the fence in response to a complaint filed by the accused. ${ }^{63}$ In another case, Valentina Cherevatenko, the chair of the NGO 'Women of the Don and laureate of the 2016 Franco-German Prize for Human Rights', was convicted for allegedly failing to register as a 'foreign agent' in the then new 'Foreign Agents' Register'. According to the Law on Amendments to Legislative Acts of the Russian Federation regarding the Regulation of the Activities of Non-profit Organisations Performing the Functions of a Foreign Agent (Foreign Agents' Act) ${ }^{64}$, any organisation receiving a certain amount of foreign funding and being engaged in 'political activities' is

$59 \mathrm{CoE}$ Department for the Execution of Judgments of the European Court of Human Rights, Country Factsheet. Russian Federation, 2020, https://rm.coe.int/rus sian-factsheet/1680764748; Human Rights Watch, Human Rights Violations in Russia's North Caucasus (2016).

60 See, for example, ECtHR, Judgment, 17 July 2014, Svinarenko and Slyadnev $v$ Russia, Application Nos. 32541/08 and 43441/08; ECtHR, Judgment, 31 January 2017, Vorontsov and Others $v$ Russia, Application No. 59655/14.

61 UN Human Rights Committee (UN HRC), Concluding observations on the seventh periodic report of the Russian Federation, 28 April 2015, UN Doc. $\mathrm{CCPR} / \mathrm{C} / \mathrm{RUS} / \mathrm{CO} / 7$.

62 Amnesty International, 'Russia: Release environmentalist banished to a prison colony', 15 April 2015, https://www.amnesty.org/en/latest/news/2015/04/russia-rel ease-yevgeniy-vitishko/.

63 Human Rights Watch, 'Russia: Flawed Trial of Environmental Activists', 21 June 2012, http://www.hrw.org/news/2012/06/21/russia-flawed-trial-environmental-acti vists.

64 Federal Law No. 121-FZ of 20 July 2012, https://www.nhc.no/content/uploads/20 14/08/ICNL-Unofficial-Translation-Russian-Enacted-Law.pdf. 
obliged to register as a 'foreign agent' with the 'foreign agent roster'. Upon registration, the organisation will be labelled as 'foreign agent' and must display the 'foreign agent label' on all its output including publications. It should be noted that the term 'foreign agent' is associated with 'spy' or 'traitor' in Russia, which may make the respective organisation less attractive to donors to secure funding. ${ }^{65}$ In the case of Ms Cherevatenko, Russian courts, again, dismissed all arguments put forward by her lawyer and limited the judicial review of her case to the issue of its formal legality. ${ }^{66}$ It is also common that Russian judges regard the evidence obtained by investigators as true and consistent without independent assessment. This is illustrated by the case of the human rights defender Oyub Titiev, a member of the Russian NGO 'Memorial', who was sentenced to a fouryear prison term to be served in a penal colony for the possession of a bag of marijuana, which had been placed and found in his car by the police. ${ }^{67}$ Another member of 'Memorial', Yuriy Dmitriyev, was also arrested and charged with allegedly producing child pornography by posting a photo of his underage stepdaughter on a social network. ${ }^{68} \mathrm{He}$ was detained and his stepdaughter taken into care. At pre-trial stage, the authorities did not include any circumstances in their assessment that could have supported the position of Mr. Dmitriyev (e.g., his low risk of escape and lack of tampering with evidence). Russian media reported that the photo of his stepdaughter had been posted without Mr. Dmitriyev's knowledge and consent. They regarded his arrest as an act of revenge against his research, where he investigated the personal details of officers of the former People's Commissariat for Internal Affairs (NKVD), which is known for its

65 Radio Free Liberty/Radio Liberty, 'How Russia Has Implemented its 'ForeignAgent' Law', 2 November 2018, http://www.rferl.org/a/foreign-agent-law/2957939 0.html.

66 Amnesty International, Attending Trials Involving Human Rights Defenders in Russia. A Handbook for Diplomats (2018), https://www.amnesty.nl/content/uploa ds/2017/01/AI-trial-attendance-handbook-for-diplomats-Russia.pdf?x55436\#; UK Foreign \& Commonwealth Office: Human Rights Priority Country Update Report: January to June 2016, 2017. http://www.gov.uk/government/publications/ russia-human-rights-priority-country/human-rights-priority-country-update-report -january-to-june-2016.

67 European Parliament, European Parliament resolution of 8 February 2018 on Russia, the case of Oyub Titiev and the Human Rights Centre Memorial, 2018/2560(RSP); Frontline Defenders, Oyub Titiev Granted Parole, 2019, https://www.frontlinedef enders.org/en/case/oyub-titiev-granted-parole.

68 Luhn, 'Gulag Grave Hunter Unearths Uncomfortable Truths in Russia', Guardian, 3 August 2017, http:/www.theguardian.com/world/2017/aug/03/gulag-grave-h unter-yury-dmitriyev-unearths-uncomfortable-truths-russia. 
political repression under Stalin. ${ }^{69}$ In Khodorkovskiy and Lebedev v. Russia, the ECtHR found a violation of Mr. Khodorkovskiy's and Mr. Lebedev's right to lawyer-client confidentiality by Russian judicial authorities. ${ }^{70}$ The lawyers of the applicants, who were senior managers of the former oil and gas company Yukos, argued that criminal charges were brought against their clients because of their political activities, particularly their financial support of opposition parties. ${ }^{71}$ While serving their sentences, following their first conviction, in penal colonies, the Deputy General Prosecutor decided to open a new case against Mr. Khodorkovskiy and Mr. Lebedev and charge them with embezzlement and money-laundering. Both men were then transferred to a remand prison in the town of Chita. When their lawyers tried to visit them, they were stopped, searched and detained by the police at Moscow airport. The police examined and video-recorded confidential papers, which were carried by the lawyers. ${ }^{72}$ Later, prior to the commencement of the trial, Mr. Khodorkovskiy and Mr. Lebedev and their lawyers were given access to one copy of the case file but which they could only study in the presence of an investigator. When they asked the investigator to discuss the bill of indictment and the appended written materials, which ran to 188 volumes, in private, the investigator took the case file from them. ${ }^{73}$ During the trial, Mr. Khodorkovskiy and Mr. Lebedev were brought to the courtroom in handcuffs, heavily guarded and held in a poorly ventilated glass dock. ${ }^{74}$ The court dismissed their requests to be near their lawyers. Thus, Mr. Khodorkovskiy and Mr. Lebedev were unable to discuss the case and review documents with their lawyers. Furthermore, their conversations with their lawyers were overheard by the guards and all documents which their lawyers wished to show them were checked by a judge before they were passed to Mr. Khodorkovskiy and Mr. Lebedev. ${ }^{75}$ The ECtHR criticised the Russian judicial authorities for breaching fundamental features of the right to a fair trial, including Mr. Khodorkovskiy's and Mr. Lebedev's right to be effectively defended by a lawyer. ${ }^{76}$ The

69 International Federation for Human Rights, Russia: Ongoing Judicial Harassment Against Yuri Dmitriyev, 3 September 2018, http://www.fidh.org/en/issues/h uman-rights-defenders/russia-ongoing-judicial-harassment-against-yuri-dmitriyev.

70 ECtHR, Judgment, 14 January 2020, Khodorkovskiy and Lebedev v Russia (No. 2), Application Nos. 51111/07 and 42757/07, para. 533.

71 Id. para. 7.

72 Id. para. 55.

73 Id. para. 69.

74 Id. para. 75.

75 Id. paras. $76,464,466$.

76 Id. paras. $463 \mathrm{ff}$. 
ECtHR also pointed out that the measures imposed on them to restrict their participation in the trial and communicate with their lawyers were neither necessary nor proportionate and that any legal assistance loses its usefulness when the accused's communication with her/his lawyer is overheard by a third person. ${ }^{7}$

\section{Ukraine}

Like in Azerbaijan and Russia, criminal procedural rights have long been under threat in Ukraine, partly due to a continued problem of corruption and lack of integrity within the judiciary. ${ }^{78}$ Since joining the CoE in 1995 , the Ukrainian government introduced several reforms to improve the level of independence of its judiciary. ${ }^{79}$ More recently, the 2014 'Law on Restoring of Trust in the Judicial Power in Ukraine'80 entered into force to further the internal and external independence of judges by removing all court chairmen who had served under the former president Viktor Yanukovych. Under Yanukovych's administration, these court chairmen enjoyed far-reaching competences which allowed them to control the entire judiciary: they oversaw the salary and working conditions of inferior judges, selected the new, incoming chairmen and reputedly took orders from the ruling elite to assign political sensitive cases solely to those judges who were known for their support of the government. ${ }^{81}$ In 2016, the Law on the Judiciary and Status of Judges limited the government's and parliament's influence on judicial appointments, promotions and dismissals. ${ }^{82}$

77 Id. para. 463.

78 Venice Commission, Ukraine. Joint Opinion of the Venice Commission and the Directorate General of Human Rights and the Rule of Law (DGI) of the Council of Europe on Draft Amendments to the Law 'On the Judiciary and the Status of Judges' and certain Laws on the Activities of the Supreme Court and Judicial Authorities (Draft Law No. 3711), 9 October 2020, CDL-AD(2020)022, 4.

79 CoE Parliamentary Assembly, Application by Ukraine for membership of the Council of Europe, Opinion 190 (1995), 26 September 1995.

80 Verkhovna Rada of Ukraine, 'The Verkhovna Rada of Ukraine adopted the Law "On restoring trust in the court system of Ukraine", 8 April 2014, https:/ /www.rada.gov.ua/en/news/News/News\%202/91053.html.

81 Ukrainian Bar Association, 'Concept of Judicial Reform in Ukraine', 19 September 2014, uba.ua/eng/projects/38/.

82 Law of Ukraine on the Judiciary and the Status of Judges, 16 July 2016, https://vk ksu.gov.ua/userfiles/doc/Law_on_Judiciary_and_Status_of_Judges_16\%2007\%202 016_ENG.pdf. 
The new law aimed at strengthening the role of Ukraine's judicial council, the High Council of Justice, introduced merit-based promotions for judges and led to the Supreme Court's reorganisation, which was praised by the Venice Commission. ${ }^{83}$ The Venice Commission noted that the 'time has come $[\ldots]$ to finally move towards achieving an independent judiciary' in Ukraine. ${ }^{84}$ In addition to this, Ukraine's first anti-corruption court took office in 2019 to fight the country's high levels of corruption. ${ }^{85}$ The success of these reforms, however, will depend largely on the willingness of the judiciary to comply with this new set of rules in practice. Yet progress has been slow. The judicial profession suffers from widespread bribery, delayed and fabricated initiations of criminal proceedings and a great loss of public confidence in the national judicial system. ${ }^{86}$ Only 2,9\% of the population perceived the judiciary as a fair and just institution in $2012 .{ }^{87} \mathrm{Be}-$ sides, more recent attempts to restore trust into the judicial system were unsuccessful. For instance, the Public Integrity Council (PIC), an NGO watchdog tasked with advising courts about the ethics and integrity of judicial candidates, considered 15 nominees to the Constitutional Court as not suitable for office. These nominees were regardless confirmed by the two most superior judicial bodies of Ukraine, the High Council of Justice and the High Qualification Commission of Judges, which oversee the judicial appointment process in Ukraine and led the PIC to withdraw from its

83 OSCE Office for Democratic Institutions and Human Rights, Opinion on the Law of Ukraine on the Judiciary and the Status of Judges, 30 June 2017, Opinion-Nr. JUDUKR/298/2017 [RJU/AT]; Venice Commission, Opinion on the Proposed Amendments to the Constitution of Ukraine regarding the Judiciary as Approved by the Constitutional Commission on 4 September 2015, 26 October 2015, CDL-AD(2015)027.

84 Venice Commission, Opinion on the Proposed Amendments to the Constitution of Ukraine regarding the Judiciary as Approved by the Constitutional Commission on 4 September 2015, 26 October 2015, CDL-AD(2015)027.

85 UNIAN, 'Ukraine Launches High Anti-Corruption Court', 11 April 2019, http:// www.unian.info/politics/10513461-ukraine-launches-high-anti-corruption-court.h tml.

86 World Justice Project, The World Justice Project Rule of Law Index 2019 (2019); Venice Commission, Ukraine. Joint Opinion of the Venice Commission and the Directorate General of Human Rights and the Rule of Law (DGI) of the Council of Europe on Draft Amendments to the Law 'On the Judiciary and the Status of Judges' and certain Laws on the Activities of the Supreme Court and Judicial Authorities (Draft Law No. 3711), 9 October 2020, CDL-AD(2020)022, 5.

87 Korrespondent, Корреспондент: Рівень довіри до українських судів наближається до абсолютного мінімуму, 12 October 2012, http://ua.korrespo ndent.net/ukraine/politics/1405614-korrespondent-riven-doviri-do-ukrayinskih-su div-nablizhaetsya-do-absolyutnogo-minimumu. 
advisory role to the Constitutional Court. ${ }^{88}$ Another example is the judiciary's mishandling of the 'Revolution of Dignity', the 2013-2014 mass protests against Yanukovych's administration, which became internationally known as the 'Maidan protests'. The government's violent suppression of protesters was actively supported by judges and prosecutors and resulted in about 100 people being killed, 700 people being injured and several people who went missing. ${ }^{89}$ The testimonies given by high-profile figures of Ukraine's judiciary, such as the president of Kyiv's district court and member of the High Council of Justice, Mamontova I. Yu, and the former president of Kyivshow court of appeal, Chernushenko A., show that, during the protests, judicial bodies received instructions from Yanukovych's administration to disperse the Maidan rallies which resulted in excessive arrests, detentions, kidnappings, torture and sanctions of protesters. ${ }^{90} \mathrm{Nev}$ ertheless, it seems unlikely that the 'Maidan judges' will be brought to justice in Ukraine. Following the escape of senior officials of Yanukovych's administration including Yanukovych himself and his chief prosecutor Viktor Pshonka, the prosecutor's office was tasked with investigating the crimes perpetrated at Maidan. Yet only a fraction of judges who had served under Yanukovych was removed from office and many 'Maidan judges' continued their work under the new government. ${ }^{91}$ In 2017, three 'Maidan judges' were appointed to the Supreme Court which raised doubts about the court's ability to conduct independent investigations into the Maidan events. ${ }^{92}$ In one case, two officers of the so-called Berkut regiment - a riot police unit that was dissolved by the new political leadership after the

88 Freedom House, Freedom in the World 2019 (2020); Sukhov, 'Poroshenko appoints 75 judges to Supreme Court, including 15 controversial', Kyiv Post, 7 May 2019, http://www.kyivpost.com/ukraine-politics/poroshenko-appoints-75-judges-to-supr eme-court-including-15-controversial.html.

89 UN Human Rights Monitoring Mission in Ukraine, Accountability for Killings and Violent Deaths during the Maidan Protests, Briefing Note, 2019, http://www.un.org. ua/images/documents/4700/Accountability\%20for\%20Killings\%20and\%20Violen t\%20Deaths\%20During\%20the\%20Maidan\%20Protest_2.pdf.

90 Coynash, Judge heavily implicated in persecuting Maidan activists chosen for trial of ex-President Yanukovych, Kharkiv Human Rights Protection Group, 22 August 2018, http://khpg.org/en/index.php?id=1534457393.

91 Mirovalev, 'Ukraine at crossroads five years after 'revolution of dignity", Al Jazeera, 22 February 2019, https:/www.aljazeera.com/news/2019/02/ukraine-crossroads -years-revolution-dignity-190222114802790.html.

92 Human Rights Information Centre, "Judges of EuroMaidan” have an open path to the Supreme Court', 28 April 2017, http://humanrights.org.ua/en/material/su ddjiam_majdanu_vidkrivajetsjia_doroga_u_verkhovnij_sud_maselko; Freedom House, Freedom in the World 2019 (2020). 
Maidan protests - were arrested on charges of attempted killing of 33 Maidan protesters and released from custody. They then fled to Russia where they appeared in a video, stating that they fear persecution for 'performing their constitutional duty' at Maidan. ${ }^{93}$ In another case, courts released a major of the anti-riot police unit, Dmitri Sadovnyka, and Yanukovych's former first deputy prime minister, Serhiy Arbuzov, from custody in spite of their high risk of escape. At Maidan, Mr. Sadovnyka and Mr. Arbuzov had been tasked with overseeing the police operations which led to shootings of protesters. ${ }^{94}$ Moreover, the prosecutor O. Nichiporenko has not faced any sanctions for his actions during the protests. Mr. Nichiporenko had played an active role in obstructing the course of justice at Maidan, serving as the deputy chief of Kyiv department of procedural management under Yanukovych's administration. He also featured in criminal investigations but was later promoted to a position in which he supervises the activities of Kyiv's prosecutor's office. ${ }^{95}$ Ukraine's neglect of the right to a fair trial was also discussed in Korban v. Ukraine. ${ }^{96}$ In 2015, Gennadiy Olegovych Korban, a former leader of a newly formed opposition party, was charged with embezzlement and creation of a criminal organisation, and kidnapping a public official, among others, and subsequently arrested and detained. ${ }^{97}$ His lawyers argued that the investigating judge did not provide any reason to justify the measures imposed on their client, including his house arrest. The ECtHR found that neither the applicant's arrest nor his detention were lawful as the Ukrainian investigators disregarded Mr. Korban's rights under national law. ${ }^{98}$ Additionally, the ECtHR reiterated that no person should be declared guilty before her/his conviction by a court. In the case of Mr. Korban, high-ranking officials of the governing party had informed the public of the criminal proceedings against Mr. Korban, neither discreetly nor circumspectly, and labelled him as 'the leader of a criminal organisation' in the mass media. ${ }^{99}$

93 UN Human Rights Monitoring Mission in Ukraine, 'Accountability for Killings and Violent Deaths during the Maidan Protests', Briefing Note, 2019, Fn. 21, http://www.un.org.ua/images/documents/4700/Accountability\%20for\%20Killings $\% 20$ and $\% 20$ Violent $\% 20$ Deaths\%20During\%20the\%20Maidan\%20Protest_2.pdf.

94 Sukhov, 'Yarema, top prosecutor since June, accused of stalling criminal cases', Kyiv Post, 14 October 2014, http://www.kyivpost.com/article/content/reform-watch/yar ema-top-prosecutor-since-june-accused-of-stalling-criminal-cases-367925.html.

95 Ibid.

96 ECtHR, Judgment, 4 July 2019, Korban v Ukraine, Application No. 26744/16.

97 Id. paras. 9, 15.

98 Id. paras. $145,150,162,166,175$.

99 Id. paras. 218, 230, 231. 
The ECtHR concluded that such statements violate the right to the presumption of innocence. ${ }^{100}$ In 2019, the Ukrainian government, under a new political leadership, announced to complete its long overdue judicial reform due to its poor record to implement such reforms once they are adopted. ${ }^{101}$ As a consequence, a set of legislative measures were discussed and introduced. This included the Law No. 193-IX.102 The new law foresees to reduce the Supreme Court by half and dissolved the High Qualification Commission of Judges, which left 2000 judicial vacancies at first and second instance courts unfilled in 2020.

\section{Outlook}

Azerbaijan, Russia and Ukraine committed themselves to cooperation with the $\mathrm{CoE}$ in the fields of human rights, the rule of law and democracy. ${ }^{103}$ They also ratified the ECHR including its Protocol 14 according to which they agreed to respect the ECtHR's judgments as a vital element of the CoE's system for the protection of human rights, rule of law and democracy. ${ }^{104}$ Besides, Article 46 of ECHR obliges them to abide by the final judgments of the ECtHR in any case to which they were parties. Judgments by the ECtHR against the respondent member state impose a legal obligation not just to pay those concerned the sums awarded by way of just satisfaction, but also to choose, subject to supervision by the CoE's Committee of Ministers, the general and/or, if appropriate, individual measures to be adopted in their domestic legal order to put an end to the violation found by the ECtHR and to redress so far as possible the effects. ${ }^{105}$ Considering the findings of this chapter - the systematic violation of basic procedural

100 Id. para. 232.

101 Venice Commission, Ukraine. Joint Opinion of the Venice Commission and the Directorate General of Human Rights and the Rule of Law (DGI) of the Council of Europe on Draft Amendments to the Law 'On the Judiciary and the Status of Judges' and certain Laws on the Activities of the Supreme Court and Judicial Authorities (Draft Law No. 3711), 9 October 2020, CDL-AD(2020)022, 4.

102 Law of Ukraine No. 193-IX, 2019, https://www.venice.coe.int/webforms/docume nts/default.aspx?pdffile=CDL-REF(2019)039.

$103 \mathrm{CoE}$, Department for the Execution of Judgments of the European Court of Human Rights, 2020, https://www.coe.int/en/web/execution.

$104 \mathrm{CoE}$, Department for the Execution of Judgments of the European Court of Human Rights, 2020, https://www.coe.int/en/web/execution.

105 ECtHR, Judgment (GC), 13 July 2000, Scozzari and Giunta v Italy, Application Nos. 39221/98 and 41963/98, para. 249. 
rights of activists and other government critics by judicial authorities - it has been shown that the protection and enforcement of the ECHR and the ECtHR's jurisprudence can differ strongly from country to country. Recognizing their powerful role in the delivery of justice, the international community has therefore set up working groups and other initiatives to remind judges and prosecutors of their professional obligations under international law to respect human rights. ${ }^{106}$ The Magna Carta of Judges, for example, underlines the importance of human rights to the profession of judge and requires that her/his actions should respond to human rights standards. ${ }^{107}$ The Bangalore Principles also point out that education and training are key to deliver justice as they can help judges (and students, in their role as future justices) to demystify their concern regarding international human rights law and to make more decisions that are in line with human rights standards. ${ }^{108}$ Furthermore, the international community suggests that judges who do not comply with their professional obligations under international law to respect human rights should be removed from office. ${ }^{109}$ Judges should be dismissed when they are unable to perform their judicial duties because of 'incapacity or behaviour that renders them unfit to discharge their duties' 110 , or conduct that is manifestly contrary to the independence, impartiality and integrity of the judiciary'. ${ }^{111}$ Similarly,

106 See, for example, International Association of Judges, 'The Universal Carter of the Judge', 14 November 2017, https://www.unodc.org/res/ji/import/internat ional_standards/the_universal_charter_of_the_judge/universal_charter_2017 _english.pdf, Article 1; International Association of Prosecutors, Standards of Professional Responsibility and Statement of the Essential Duties and Rights of Prosecutors, 23 April 1999, https://www.iap-association.org/getattachment/Reso urces-Documentation/IAP-Standards-(1)/English.pdf.aspx, 3(e), (f).

107 See, for example, CCJE, 'Magna Carta of Judges (Fundamental Principles)', 17 November 2010, https://rm.coe.int/2010-ccje-magna-carta-anglais/168063e431, paras. 5,11 .

108 See, for example, UN Economic and Social Council, Strengthening basic principles of judicial conduct, Annex, Bangalore Principles of Judicial Conduct, 27 July 2006, UN Doc. E/Res/2006/23, preamble; Venice Commission, Co-operation with Central Asia, Highlights, https://www.venice.coe.int/WebForms/pages/?p=03 _Central_asia.

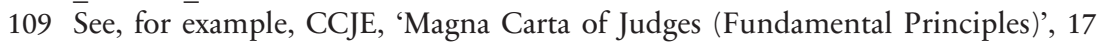
November 2010, https://rm.coe.int/2010-ccje-magna-carta-anglais/168063e431, para. 19.

110 UN, Seventh UN Congress on the Prevention of Crime and Treatment of Offenders, Milan, 26 August-6 September 1985, Basic Principles on the Independence of the Judiciary (1986), 58 para. 18.

111 International Commission of Jurists, Judicial Accountability. A Practitioners' Guide (2016), https://www.icj.org/wp-content/uploads/2016/06/Universal-PG-13-Ju 
the professional responsibility of prosecutors to respect human rights is reflected and referred to in law, regulation, bilateral contracts and litigation. ${ }^{112}$ Thus, prosecutors, like judges, should be held accountable when they fail to comply with their professional duties under international law.

In many countries, independent and impartial bodies such as judicial councils have the role to oversee and enforce professional discipline (e.g., to ensure that judges respect European human rights standards). ${ }^{113}$ If the judiciary and the prosecution, however, are controlled by the government and independent and impartial disciplinary bodies are absent, they will be less likely to oppose unlawful orders by superiors and be held responsible for their misconduct. Not surprisingly, judges in Azerbaijan, Russia and Ukraine do rarely face disciplinary or criminal consequences for their misconduct. Additionally, there are currently no credible audit or monitoring instruments at international or European level in place that could oversee actions of and impose sanctions on judges and prosecutors who fail to comply with their human rights obligations under international law in $\mathrm{CoE}$ member countries. Complaints and reporting mechanisms provided by, for example, the UN do not periodically review or sanction the human rights violations of judicial authorities and are often only mandated to adopt 'concluding observations'. ${ }^{114}$ Addressing the accountability of judges and public prosecutors also falls short at European level. The ECtHR, for instance, has the authority to review a country's judicial wrongdoings in

dicial-Accountability-Publications-Reports-Practitioners-Guide-2016-ENG. pdf; UN HRC, Concluding observations on the seventh periodic report of the Russian Federation, 28 April 2015, UN Doc. CCPR/C/RUS/CO/7; Judicial Integrity Group, 'Measures for the Effective Implementation of the Bangalore Principles of Judicial Conduct', 21/22 January 2010, https:/www.unodc.org/res/ji/import/i nternational_standards/measures_implementation/measures_implementation.p df, para. 16.1.

112 ECtHR, Judgment, 22 February 1996, Bulut v Austria, Application No. 17358/90; ECtHR, Judgment, 26 July 2011, Huseyn and Others $v$ Azerbaijan, Application No. 35485/05 and 3 more; ECtHR, Judgment, 22 May 2014, Ilgar Mammadov $v$ Azerbaijan, Application No. 15172/13; ECtHR, Judgment, 17 July 2014, Svinarenko and Slyadnev v Russia, Application Nos. 32541/08 and 43441/08; ECtHR, Judgment, 17 March 2016, Rasul Jafarov v Azerbaijan, Application No. 69981/14.

113 See UN HRC, General Comment No. 32, 23 August 2007, UN Doc. CCPR/C/GC/32, para. 20; International Bar Association, IBA Minimum Standards of Judicial Independence (1982), https://www.ibanet.org/Publications/public ations_IBA_guides_and_free_materials.aspx, 4(a).

114 See, for example, $\bar{U} \mathrm{~N}$ Working Group on Arbitrary Detention, Opinion, 7 July 2015, Thulani Maseko v Swaziland, No. 6/2015, UN Doc. A/HRC/WGAD/2015/6, paras. $26 \mathrm{ff}$. 
$\mathrm{CoE}$ member countries and issue decisions on individual complaints of human rights abuse perpetrated by or with complicity of judges and prosecutors. But rulings focusing on political motivated charges and convictions by judicial authorities are rare in practice.

Nevertheless, there is much promising (but yet underutilised) potential at both international and European level. International organisations are capable to strengthen the professional integrity of judges and prosecutors and increase their awareness of human rights standards. For instance, the Bureau of the Consultative Council of European Judges (CCJE) and the Bureau of the Consultative Council of European Prosecutors (CCPE) are uniquely placed to draw attention to the situation of activists and other regime critics as they are tasked with looking into specific problems concerning the status and the situation of judges and public prosecutors. ${ }^{115}$ Yet they have not set up institutional human rights mechanisms, such as requiring members to complete an annual questionnaire and organising country visits to identify best practices that could help the CCJE's and CCPE's to step up their professional integrity polices. Besides, establishing an 'urgent appeal' procedure for cases in which the CCJE and the CCPE may play a role in preventing or mitigating human rights abuses by judicial authorities of the Council of Europe member states (e.g., in situations in which physical and/or mental integrity of an individual or a group is concerned) could contribute to important change in countries, such as Azerbaijan, Russia and Ukraine, where the rights of anti-government critics are neglected in the courts.

\section{Bibliography}

Amnesty International: Unfair Game, Persecution of Human Rights Defenders in Russia Intensifies (2019), https://www.amnesty.org/download/Documents/EUR4 609502019ENGLISH.pdf.

Amnesty International: Amnesty International Report 2017/18. The State of the World's Human Rights (2018).

115 See for example, CCJE, 'Framework Global Action Plan for Judges in Europe', CCJE(2001)24, 12 February 2001; CCJE, 'Magna Carta of Judges (Fundamental Principles)', 17 November 2010, https://rm.coe.int/2010-ccje-magna-carta-angla is/168063e431; CoE Committee of Ministers, Judges: independence, efficiency and responsibilities, 17 November 2010, Recommendation CM/Rec(2010)12. 
Amnesty International: Attending Trials Involving Human Rights Defenders in Russia. A Handbook for Diplomats (2018), https:/www.amnesty.nl/content/upl oads/2017/01/AI-trial-attendance-handbook-for-diplomats-Russia.pdf?x55436\#.

Amnesty International: Russia: Release environmentalist banished to a prison colony, 15 April 2015, https://www.amnesty.org/en/latest/news/2015/04/russ ia-release-yevgeniy-vitishko/.

Closed Society: Implications of Implementing the Legislation Regulating the Activities of "Non-Commercial Organisations Performing the Functions of a Foreign Agent" in Russia (2015), https://www.osce.org/files/f/documents/6/8/151581.pdf.

Consultative Council of European Judges (CCJE): Framework Global Action Plan for Judges in Europe, CCJE, 12 February 2001.

Consultative Council of European Judges (CCJE): Magna Carta of Judges (Fundamental Principles), 17 November 2010, https://rm.coe.int/2010-ccje-magna-carta -anglais/168063e431.

Coynash, Halya: Judge heavily implicated in persecuting Maidan activists chosen for trial of ex-President Yanukovych, Kharkiv Human Rights Protection Group, 22 August 2018, http://khpg.org/en/index.php?id=1534457393.

Domingo, Pilar: Judicial Independence and Judicial Reform in Latin America, in: Schedler, Andreas/Diamond, Larry Jay/Plattner, Marc F. (eds), The Self-Restraining State: Power and Accountability in New Democracies (1999), $151 \mathrm{ff}$.

Fiss, Owen M.: The Right Degree of Independence, in: Strotzky, Irwin P. (ed), Transition to Democracy in Latin America: The Role of the Judiciary (1993), $55 \mathrm{ff}$.

Freedom House: Freedom in the World 2020 (2021).

Freedom House: Freedom in the World 2019 (2020).

Frontline Defenders: Oyub Titiev Granted Parole (2019), https://www.frontlinedefe nders.org/en/case/oyub-titiev-granted-parole.

Human Rights Information Centre: "Judges of EuroMaidan" have an open path to the Supreme Court, 28 April 2017, http://humanrights.org.ua/en/material/suddji am_majdanu_vidkrivajetsjia_doroga_u_verkhovnij_sud_maselko.

Human Rights Watch: Crimea: Defence Lawyers Harassed, Drop Bogus Charges Against Crimean Tatars (2017), https:/www.hrw.org/news/2017/01/30/crimea-d efense-lawyers-harassed.

Human Rights Watch: Human Rights Violations in Russia's North Caucasus, 28 January 2016, https:/www.hrw.org/news/2016/01/28/human-rights-violations-ru ssias-north-caucasus.

Human Rights Watch: Laws of Attrition. Crackdown on Russia's Civil Society after Putin's Return to the Presidency (2013).

Human Rights Watch: Russia: Flawed Trial of Environmental Activists. Dubious Charges, Harsh Sentences Seem Designed to Silence Zoologist, Geologist, 21 June 2012, http://www.hrw.org/news/2012/06/21/russia-flawed-trial-environmen tal-activists. 
International Association of Judges: The Universal Carter of the Judge, 14 November 2017, https://www.unodc.org/res/ji/import/international_standards/the_univ ersal_charter_of_the_judge/universal_charter_2017_english.pdf.

International Association of Prosecutors: Standards of Professional Responsibility and Statement of the Essential Duties and Rights of Prosecutors, 23 April 1999, https:/www.iap-association.org/getattachment/Resources-Documentation/IAP-S tandards-(1)/English.pdf.aspx.

International Bar Association, IBA Minimum Standards of Judicial Independence (1982), https://www.ibanet.org/Publications/publications_IBA_guides_and_free _materials.aspx.

International Commission of Jurists: Judicial Accountability. A Practitioners' Guide (2016), https://www.icj.org/wp-content/uploads/2016/06/Universal-P G-13-Judicial-Accountability-Publications-Reports-Practitioners-Guide-2016-EN G.pdf

International Federation for Human Rights: Russia: Ongoing Judicial Harassment Against Yuri Dmitriyev, 3 September 2018, http://www.fidh.org/en/issues/huma n-rights-defenders/russia-ongoing-judicial-harassment-against-yuri-dmitriyev.

Jackson, Vicki C.: Judicial Independence: Structure, Context, Attitude, in: SeibertFohr, Anja (ed.), Judicial Independence in Transition (2012), 19 ff.

Judicial Integrity Group: Measures for the Effective Implementation of the Bangalore Principles of Judicial Conduct, 21/22 January 2010, https://www.unodc.org/ res/ji/import/international_standards/measures_implementation/measures_impl ementation.pdf.

Korrespondent: Корреспондент: Рівень довіри до українських судів наближається до абсолютного мінімуму, 12 October 2012, http://ua.korrespondent.net/ukrain e/politics/1405614-korrespondent-riven-doviri-do-ukrayinskih-sudiv-nablizhaetsy a-do-absolyutnogo-minimumu.

Luhn, Alec: Gulag Grave Hunter Unearths Uncomfortable Truths in Russia, Guardian, 3 August 2017, http://www.theguardian.com/world/2017/aug/03/ gulag-grave-hunter-yury-dmitriyev-unearths-uncomfortable-truths-russia.

Mirovalev, Mansur: Ukraine at crossroads five years after 'revolution of dignity', Al Jazeera, 22 February 2019, https://www.aljazeera.com/news/2019/02/ukraine-cro ssroads-years-revolution-dignity-190222114802790.html.

Myjer, Egbert/Hancock, Barry/Cowdery, Nicholas (eds), Human Rights Manual for Prosecutors (2008).

OSCE: Azerbaijan Election Lacked Genuine Competition in an Environment of Curtailed Rights and Freedoms, International Observers Say, 12 April 2018, http://www.osce.org/odihr/elections/azerbaijan/377623.

OSCE: Trial Monitoring Report: Azerbaijan (2011), www.osce.org/baku/100593.

OSCE Office for Democratic Institutions and Human Rights: Opinion on the Law of Ukraine on the Judiciary and the Status of Judges, Opinion-Nr. JUDUKR/298/2017 [RJU/AT], 30 June 2017. 
Radio Free Liberty/Radio Liberty: How Russia Has Implemented its 'ForeignAgent' Law, 2 November 2018, http://www.rferl.org/a/foreign-agent-law/295 79390.html.

Shapiro, Martin/Stone Sweet, Alec: Law, Courts and Social Science, in: Shapiro, Martin/Stone Sweet, Alec (eds), On Law, Politics and Judicialization (2002), $1 \mathrm{ff}$.

Sukhov, Oleg: Poroshenko appoints 75 judges to Supreme Court, including 15 controversial, Kyiv Post, 7 May 2019, http://www.kyivpost.com/ukraine-politics /poroshenko-appoints-75-judges-to-supreme-court-including-15-controversial.ht $\mathrm{ml}$.

Sukhov, Oleg: Yarema, top prosecutor since June, accused of stalling criminal cases, Kyiv Post, 14 October 2014, http://www.kyivpost.com/article/content/refo rm-watch/yarema-top-prosecutor-since-june-accused-of-stalling-criminal-cases-36 7925.html.

The Prosecutor General's Office of the Russian Federation: Report. Order of 27 December 2012, N 27-07-2012/14п1861-12в, 2012, http://genproc.gov.ru/smi/i nterview_and_appearences/appearences/83568/.

Transparency International: Azerbaijan: Overview of Corruption and Anti-Corruption, 7 September 2017, https://knowledgehub.transparency.org/assets/uploads/ helpdesk/Country-Profile-Azerbaijan-2017_PR.pdf.

Transparency International: Global Corruption Report 2007 (2007).

UK Foreign \& Commonwealth Office: Human Rights Priority Country Update Report: January to June 2016 (2017), http://www.gov.uk/government/publicatio ns/russia-human-rights-priority-country/human-rights-priority-country-update-re port-january-to-june-2016.

Ukrainian Bar Association: Concept of Judicial Reform in Ukraine, 19 September 2014, uba.ua/eng/projects/38/.

UN: Seventh UN Congress on the Prevention of Crime and Treatment of Offenders, Milan, 26 August-6 September 1985 (1986).

UN: Eighth UN Congress on the Prevention of Crime and Treatment of Offenders, Havana, 27 August-7 September 1990 (1990).

UN Committee against Torture (UN CAT): Concluding observations on the fourth periodic report of Azerbaijan, UN Doc. CAT/C/AZE/CO/4, 27 January 2016.

UN Economic and Social Council: Strengthening basic principles of judicial conduct, Annex, Bangalore Principles of Judicial Conduct, UN Doc. E/Res/2006/23, 27 July 2006.

UN Human Rights Committee (UN HRC): Concluding observations on the seventh periodic report of the Russian Federation, UN Doc. CCPR/C/RUS/CO/7, 28 April 2015.

UN Human Rights Committee (UN HRC): General Comment No. 31. The Nature of the General Legal Obligation Imposed on States Parties to the Covenant, UN Doc. CCPR/C/21/Rev.1/Add. 13, 26 May 2004.

UN Human Rights Committee (UN HRC): General Comment No. 32. Article 14: Right to equality before courts and tribunals and to a fair trial, UN Doc. CCPR/C/GC/32, 23 August 2007. 
UN Human Rights Committee (UN HRC): Report of the Special Rapporteur on the situation of human rights defenders, Margaret Sekaggya, UN Doc. A/HRC/25/55, 23 December 2013.

UN Human Rights Monitoring Mission in Ukraine: Briefing Note. Accountability for Killings and Violent Deaths during the Maidan Protests (2019), http://www. un.org.ua/images/documents/4700/Accountability $\% 20$ for $\% 20$ Killings $\% 20$ and $\%$ 20Violent\%20Deaths\%20During\%20the\%20Maidan\%20Protest_2.pdf.

UN Office on Drugs and Crime (UNODC): The Status and Role of Prosecutors. A UN Office on Drugs and Crime and International Association of Prosecutors Guide (2014), https://www.unodc.org/documents/justice-and-prison-reform/HB _role_and_status_prosecutors_14-05222_Ebook.pdf.

UN Special Rapporteur on the Independence of Judges and Lawyers: Information on Hungary: Hungary: More Needs to Be Done to Bring Legislation on Administrative Courts in line with International Standards, UN Expert Says (2019), https:/www.ohchr.org/Documents/Issues/IJudiciary/InfoNoteHungary8Apr201 9.docx.

UNIAN: Ukraine Launches High Anti-Corruption Court, 11 April 2019, http://ww w.unian.info/politics/10513461-ukraine-launches-high-anti-corruption-court.ht $\mathrm{ml}$.

Verkhovna Rada of Ukraine: The Verkhovna Rada of Ukraine adopted the Law "On restoring trust in the court system of Ukraine", 8 April 2014, https:/www.r ada.gov.ua/en/news/News/News\%202/91053.html.

World Justice Project: The World Justice Project Rule of Law Index 2019 (2019). 